\title{
PENGARUH KUALITAS PELAYANAN TERHADAP KEPUASAN PELANGGAN DI AHASS SUMBER JAYA MAHA SAKTI KECAMATAN ROGOJAMPI KABUPATEN BANYUWANGI
}

\author{
Ludviyatus Sholeha ${ }^{1}$, Sutrisno Djaja ${ }^{1}$, Joko Widodo ${ }^{1}$ \\ ${ }^{1}$ Program Studi Pendidikan, Fakultas Keguruan dan Ilmu Pendidikan, Universitas Jember \\ e-mail: sutrisnodjaja.fkip@unej.ac.id
}

\begin{abstract}
Abstrak
Penelitian dengan judul Pengaruh Kualitas Pelayanan Terhadap Kepuasan Pelanggan AHASS Sumber Jaya Maha Sakti Kecamatan Rogojampi Kabupaten Banyuwangi bertujuan untuk mengetahui pengaruh signifikan kualitas pelayanan terhadap kepuasan pelanggan di AHASS Sumber Jaya Maha Sakti Motor Kecamatan Rogojampi Kabupaten Banyuwangi. Penelitian ini menggunakan penelitian deskriptif kuantitatif. Lokasi penelitian adalah AHASS Sumber Jaya Maha Sakti Kecamatan Rogojampi Kabupaten Banyuwangi. Penentuan responden menggunakan metode populasi yang diambil secara purposive sejumlah 90 responden. Metode pengumpulan data menggunakan angket, wawancara, observasi dan dokumen. Penelitian ini menggunakan uji validitas, uji reliabilitas, analisis regresi linier sederhana, analisis varian garis regresi, efektibitas garis regresi, uji f dan standart error of estimate. Hasil penelitian menunjukkan bahwa kualitas pelayanan memiliki pengaruh signifikan terhadap kepuasan pelanggan di AHASS Sumber Jaya Maha Sakti Motor Kecamatan Rogojampi Kabupaten Banyuwangi. Berdasarkan hal tersebut maka Ho ditolak dan Ha diterima yaitu 'ada pengaruh yang signifikan kualitas pelayanan terhadap kepuasan pelanggan di AHASS Sumber Jaya Maha Sakti Kecamatan Rogojampi Kabupaten Banyuwangi'. Hasil analisis efektivitas garis regresi (R2) sebesar 79\%. Hal ini menunjukkan bahwa besarnya persentase pengaruh kualitas pelayanan terhadap kepuasan pelanggan di AHASS Sumber Jaya Maha Sakti Kecamatan Rogojampi Kabupaten Banyuwangi sebesar 79\%. Berdasarkan hasil penelitian tersebut dapat disimpulkan bahwa kualitas pelayanan memiliki pengaruh signifikan terhadap kepuasan pelanggan di AHASS Sumber Jaya Maha Sakti Kecamatan Rogojampi Kabupaten Banyuwangi.
\end{abstract}

Kata Kunci: Kualitas pelayanan, kepuasan pelanggan

\section{PENDAHULUAN}

Seiring dengan pertumbuhan penduduk yang semakin pesat, kebutuhan penduduk pun semakin meningkat, khususnyakebutuhan terhadap transportasi. Transportasi merupakan salah satu kebutuhan masyarakat untuk membantu mobilitas mereka agar sampai di suatu tempat.Transportasi yang banyak digunakan oleh masyarakat yaitu kendaraan sepeda motor. Dengan banyaknya kebutuhan masyarakat terhadapsepeda motor, semakin berkembang pula pasar kendaraan bermotor. Berkembangnya pasar sepeda motor di Indonesia membuat persaingan menjadi sangat ketat.Hal ini menjadi keuntungan bagi pihak konsumen karena akan semakin banyak pilihan dalam menentukan sepeda motor yang akan digunakan.Penentuan pilihan untuk membeli sepeda motor oleh konsumen dapat dipengaruhi banyak faktor, baik dari harga jual, pelayanan purna jual, kualitas sepeda motor, dan sebagainya.

Setiap kendaraan pasti membutuhkan perawatan berkala untuk menjaga performasi, keamanan, dan kenyamanan maksimal. Ketika terjadi kerusakan pada saat digunakan (mogok) banyak pengguna motor yang tidak bisa memperbaikinya karena pengetahuan tentang kendaraanya yang minim. Hal ini menjadi suatu peluang usaha yang dapat dimanfaatkan untuk membuka jasa layanan service motor.

Adanya peluang usaha dalam jasa layanan service sepeda motor membuat banyak pengusaha yang tertarik membuka usaha tersebut. Contohnya di daerah Kecamatan Rogojampi, banyak sekali outlet bengkel yang dibuka di beberapa titik, seperti dipusat keramaian masyarakat.Baik bengkel yang tidak resmi maupun bengkel yang resmi banyak terdapat di Kecamatan Rogojampi. Disetiap bengkel pastimemiliki fasilitas dan peralatan yang berbeda.Utamanya bagian mekanik yang melayani pelanggan 
yang membutuhkan jasa service. Adanya perasaingan antar pengusaha bengkel yang semakin ketat juga mendorong perusahaan kendaraan motor untuk mendirikan jasa layanan service motor.

Peningkatan kualitas pelayanan merupakan salah satu strategi pemasaran yang diutamakanterhadap pemenuhan keinginan pelanggan.Untuk menciptakan kualitas layanan yang tinggi, sebuah perusahaan harus menawarkan layanan yang mampu diterima dan dirasakan pelanggan sesuai dengan atau bahkan melebihi harapan pelanggan. Semakin tinggi kualitas pelayanan yang dirasakan, pelanggan tentu akan semakin puas. Kepuasan yang dirasakan pelanggan, akan berdampak positif bagi perusahaan, diantaranya akan mendorong terciptanya loyalitas pelanggan dan reputasi perusahaan akan semakin positif bagi masyarakat, khususnya bagi para pelanggan. Oleh karena itu, setiap perusahaan perlu berupaya memahami harapan pelanggan atas produk yang dihasilkan atau jasa/layanan yang diberikan. Menurut Parasuraman, dalam Tjiptono (2006:70) terdapat lima aspek penting yang harus diperhatikan dalam kualitas jasa pelayanan, yaitu:.Bukti fisik (Tangibles), Keandalan (Reliability), Daya tanggap (Responsiveness), Jaminan (Assurance), Empati (Emphaty).

Perusahaan Honda mendirikan jasa layanan service dengan nama AHASS. Di bengkel AHASS tersebut hanya melayani service untuk sepeda motor merek Honda. Bengkel AHASS juga menyediakan berbagai macam keperluan atau yang biasa disebut dengan nama spare partkhusus untuk sepeda motor yang diproduksi oleh perusahaan Honda sendiri. Diantaranya menyediakan service terkait busi, double tube, cairan pendingin, accu, oli MPX, dan masih banyak lagi. Hal tersebut membuat pelanggan yang melakukan perawatan sepeda motornya di AHASS dapat terjamin karena semua yang disediakan merek Honda. Biasanya pelanggan AHASS yang menggunakan jasa servicetersebut mempunyai buku serviceyang bisa mencatat jangka waktu pelanggan tidak melakukan service sepeda motornya.

Setiap pelanggan yang membeli produk atau jasa pasti ingin mendapatkan kepuasan yang maksimal dari produk atau jasa yang telah mereka beli.Dengan ini, perusahaan yang menghasilkan produk atau jasa harus meningkatkan kualitas pelayanan agar pelanggan yang telah membeli produk atau jasa merasa puas. AHASS juga mengutamakan kualitas pelayanan dalam memberikan service sepeda motor kepada pelanggan.

AHASS Sumber Jaya Maha Sakti Rogojampi merupakan salah satu bengkel resmi untuk sepeda motor merek Honda atau biasa disebut sebagai AHASS (Astra Honda Authorised Service Station) yang memiliki lokasi yang strategis di kawasan kota yaitu di JL. Raya Rogojampi No.70 Banyuwangi.Kondisi tersebut menjadikan AHASS Sumber Jaya Maha Sakti Rogojampi sebagai bengkel resmi Honda yang memiliki pemakai jasa atau pelanggan yang cukup tinggi. Jumlah rata-rata pelanggan perhari sampai dengan 20 pelanggan, ini dibuktikan dari data yang diperoleh dari AHASS Sumber Jaya Maha Sakti Rogojampi selama bulan Desember 2016 hingga Februari 2017.

Selain itu setiap bengkel resmi Honda (AHASS) ditunjang oleh para mekanik yang merupakan tenaga terampil dan terdidik. Para mekanik tersebut telah menjalani pelatihan mekanik tingkat I, II dan III, maupun manajemen serta menggunakan peralatan, perlengkapan teknis dan administrasi standar Astra Honda Motor. Dengan demikian, karyawan dapat memberi tahu konsumen mengenai cara merawat sepeda motor Honda secara berkala yang baik dan benar agar sepeda motor Honda tetap awet, nyaman dan aman bagi pengendara.

Sebagai perusahaan yang bergerak di bidang jasa, AHASS harus bisa memberikan kepuasan atas pelayanannya.Kepada pelanggan yang puas dengan kualitas jasa yang diberikan oleh AHASS cenderung menjadi loyal dan setia untuk terus menggunakan jasa AHASS tersebut. Sedangkan konsumen yang kurang puas atau tidak puas memiliki kecenderungan untuk beralih kepada perusahaan sejenis yang lain yang mampu menawarkan jasa dengan kualitas yang lebih baik. Oleh karena itu, AHASS diharapkan dapat meningkatkan kinerjanya, dimulai dengan mengetahui sejauh mana tingkat kepuasan yang diperoleh pelanggan.Hal itu diwujudkan dengan penyaranan kepada pelanggan dalam 
penggantian suku cadang sepeda motor ketika suku cadang tersebut mengalami kerusakan sedikit karna AHASS ingin memberikan rasa aman ketika pelanggan menggunakan sepeda motornya setelah melakukan service, mencuci sepeda motor yang melakukan service di AHASS.

Berdasarkan latar belakang diatas dan melihat betapa pentingnya kualitas jasa dalam rangka mewujudkan kepuasan pelanggan, maka peneliti tertarik untuk melakukan penelitian dengan judul "Pengaruh Kualitas Pelayanan Terhadap Kepuasan Pelanggan di AHASS Sumber Jaya Maha Sakti Kecamatan Rogojampi Kabupaten Banyuwangi”.

Berdasarkan uraian diatas, maka rumusan masalah dalam penelitian ini adalah adakah pengaruh yang signifikan dari kualitas pelayanan terhadap kepuasan pelanggan di AHASS Sumber Jaya Maha Sakti Motor Kecamatan Rogojampi Kabupaten Banyuwangi. Dengan demikian, penelitian ini bertujuan untuk mengetahui adanya pengaruh signifikan kualitas pelayanan terhadap kepuasan pelanggan di AHASS Sumber Jaya Maha Sakti Motor Kecamatan Rogojampi Kabupaten Banyuwangi.

\section{Kualitas Pelayanan}

Modernitas dengan kemajuan teknologi akan mengakibatkan persaingan yang sangat ketat untuk memperoleh dan mempertahankan pelanggan. Kualitas pelayanan menjadi suatu keharusan yang harus dilakukan perusahaan supaya mampu bertahan dan tetap mendapat kepercayaan pelanggan. Pola konsumsi dan gaya hidup pelanggan menuntut perusahaan mampu memberikan pelayanan yang berkualitas. Keberhasilan perusahaan dalam memberikan pelayanan yang berkualitas dapat ditentukan dengan pendekatan service quality yang telah dikembangkan oleh Parasuraman, Berry dan Zenthaml ( Lupiyoadi, 2006: 181).

Kualitas menunjuk pada pengertian pemenuhan standar atau persyaratan tertentu, kualitas juga mempunyai pengertian sebagai upaya untuk melakukan perbaikan dan penyempurnaan secara terusmenerus untuk memenuhi kebutuhan pelanggan sehingga dapat memuaskan pelanggan .kualitas diartikan sebagai suatu kondisi dinamis dimana yang berhubungan dengan produk, jasa , manusia, proses dan lingkungan yang memenuhi atau melebihi harapan (Tjiptono,2007:51). Selanjutnya (Tjiptono,2005:11) mendefinisikan kualitas sebagai kecocokan untuk pemakaian (fitness for use). Definisi ini menekankan orientasi pada pemenuhan harapan pelanggan yang dalam penelitian ini adalah pelanggan.

Definisi mutu jasa berpusat pada pemenuhan kebutuhan dan keinginan pelanggan serta ketepatan penyampaian untuk mengimbangi harapan pelanggan. Menurut Wyckof (dalam Tjiptono,2011) kualitas jasa adalah tingkat keunggulan yang diharapkan dan pengendalian atas tingkat keunggulan untuk memenuhi keinginan pelanggan. Apabila jasa yang diterima sesuai dengan yang diharapkan, maka kualitas jasa dipersepsikan baik dan memuaskan.Jika jasa yang diterima melampaui harapan pelanggan, maka kualitas jasa dipersepsikan ideal.Sebaliknya jika jasa yang diterima lebih rendah dari pada yang diharapkan, maka kualitas jasa dianggap buruk (Tjiptono, 2005:121).Mengacu pada pengertian kualitas layanan tersebut maka konsep kualitas layanan adalah suatu daya tanggap dan realitas dari jasa yang diberikan perusahaan.

Berdasarkan uraian diatas dapat disimpulkan bahwa kualitas pelayanan yang diharapkan oleh pelanggan sebagai penerima layanan mengharapkan tingkat keunggulan dari setiap jasa pelayanan yang didapat dari pelayanan yang didapatkan sebelumnya. Jika pelayanan yang diberikan melampaui harapan pelanggan maka kualitas pelayanan yang diberikan akan mendapatkan persepsi yang ideal dari para penerima pelayanan.

Parasuraman, Zeithaml, dan Berry dalam Beteson (dalam Tjiptono,2008:95) terdapat lima unsur yang menentukan kualitas jasa, yaitu: "tangible, responsiveness, reability, assurance, dan empathy". 


\section{Kepuasan Pelanggan}

Menurut Kotler dalam Mts. Arief (2007: 167) yang dimaksud dengan kepuasan pelanggan adalah tingkat perasaan senang seseorang setelah antara kinerja yang ia rasakan terhadap harapannya. Menurut Yazid (2008:55) kepuasan merupakan perbedaan antara harapan dan kinerja.Apabila harapan tinggi sementara kinerja biasa saja maka kepuasan tidak tercapai, sebaliknya bila kinerja melebihi harapan maka kepuasan meningkat. Teori kepuasan konsumen didasarkan pada upaya meminimalkan gap (kesenjangan) tersebut. Kepuasan konsumen akan terpenuhi apabila proses penyampaian jasa sesuai dengan yang dipersepsikan konsumen.

Anderson (dalam Tjiptono,2007:348) menyatakan kepuasan pelanggan merupakan kontribusi pada sejumlah aspek krusial, seperti terciptanya loyalitas pelanggan, meningkatnya reputasi perusahaan, berkurangnya elastisitas harga, berkurangnya biaya transaksi masa depan, dan meningkatnya efisiensi dan produktifitas karyawan. Berdasarkan definisi tersebut, dapat disimpulkan bahwa kepuasan pelanggan adalah ketiadaan perbedaan antara harapan pelanggan dengan unjuk kerja perusahaan yang diterimanya selama menjadi pelanggan. Setelah membandingkan antara harapan dengan kinerja personil layanan jasa yang telah diterima pelanggan merasa puas atau tidak kecewa apabila kinerjanya sesuai dengan harapan atau bahkan melebihinya.

Adapun indikator dari kepuasan pelanggan yang digunakan dalam penelitian ini meliputi pertama, Menggunakan jasa layanan AHASS kembali. Adanya kepuasan yang dirasakan pelanggan akan pelayanan dapat memberikan nilai positif dan memungkinkan pelanggan menggunakan jasa layanan kembali. Dan kedua, merekomendasikan layanan AHASS kepada orang lain. Kesediaan dalam merekomendasikan kepada orang lain akan menjadikan tolok ukur yang digunakan dalam mengukur kepuasan pelanggan.

\section{Pengaruh Kualitas Pelayanan Terhadap Kepuasan Pelanggan}

Kualitas pelayanan merupakan syarat kelangsungan hidup perusahaan, tingginya kualitas yang diberikan akan mencerminkan pada aspek kepuasan para pelanggan. Menurut Alma (2000:279) hal penting perusahaan dalam menjalankan usahanya adalah penerapan kualitas pelayanan sehingga tercapai kepuasan pelanggan yang pada akhirnya meningkatkan loyalitas konsumen dan tidak terbujuk untuk berpindah perusahaan lain. Hal tersebut dikuatkan dari Lupiyoadi dan Hamdani (2006:192) yang menyatakan bahwa kualitas memiliki hubungan yang erat dengan kepuasan pelanggan. Salah satu faktor yang menentukan kepuasan pelanggan adalah persepsi pelanggan mengenai kualitas pelayanan yang terdiri dari lima dimensi yaitu bukti fisik, keandalan, daya tanggap, jaminan, empati (Rangkuti, 2002:41).

Berdasarkan pendapat diatas kepuasan pelanggan akan tercipta apabila kualitas pelayanan yang diberikan perusahaan baik dan sesuai dengan harapan dan kebutuhan pelanggan namun jika kualitas yang diberikan rendah maka akan mengakibatkan rasaketidakpuasan dari pelanggan. Kepuasan pelanggan akan membentuk persepsi yang positif terhadap perusahaan dan pelayanan yang bermutu dapat dilakukan dengan meningkatkan kualitas pelayanan. Maka dari itu AHASS mengutamakan kepuasan pelanggan dengan memberikan kualitas pelayanan yang baik.

\section{METODE}

Jenis penilitian ini adalah penelitian kuantitatif yang menggunakan analisis statistik.Hasil dari analisis disajikan dalam bentuk angka-angka kemudian dijelaskan dan diinterprestasikan dalam suatu uraian. Penelitian ini menggunakan pengaruh variabel kualitas pelayanan (X) yang terdiri dari bukti fisik (X1.1), keandalan (X1.2), daya tanggap (X1.3), jaminan (X1.4), empati (X1.5) terhadap kepuasan 
pelanggan (Y) di AHASS Sumber Jaya Maha Sakti Kecamatan Rogojampi pada tahun 2017. Pengumpulan data menggunakan metode angket, observasi, wawancara dan dokumen. Teknik analisis data yang digunakan adalah analisis inferensial (regresi sederhana, uji F).

Penentuan lokasi dalam penelitian ini menggunakan metode purposive area yaitu penentuan lokasi penelitian berdasarkan kesenjangan dan pertimbangan sesuai tujuan dalam penelitian.Penelitian ini dilakukan di AHASS Jl. Raya Rogojampi No. 70 Kecamatan Rogojampi Kabupaten Banyuwangi. Pertimbangan peneliti dalam menentukan lokasi sebagai berikut:

1. Letak lokasi yang terjangkau oleh masyarakat.

2. Data yang digunakan sebagai bahan penelitian cukup memadai dan mudah diperoleh.

3. Belum ada penelitian sejenis yang dilakukan di tempat tersebut.

4. Adanya kerjasama yang baik antara pihak AHASS dan peneliti sehingga memperlancar penelitian ini.

Populasi dalam penelitian ini adalah pelanggan yang menggunakan jasa pelayanan dari AHASS Sumber Jaya Maha Sakti Kecamatan Rogojampi Kabupaten Banyuwangi. Metode sampling dalam penelitian ini menggunakan metode purposive sampling dengan teknik accidental sampling. Purposive sampling adalah teknik penentuan sampel dengan pertimbangan tertentu yang sesuai dengan tujuan penelitian. Accidental sampling adalah teknik penentuan sampel berdasarkan kebetulan, yaitu pelanggan AHASS yang secara kebetulan bertemu dengan peneliti dapat digunakan sebagai sampel dan cocok sebagai sumber data.Sampling pengambilan responden di AHASS adalah pelanggan yang menggunakan jasa pelayanan AHASS lebih dari 2 kali yang tidak menggunakan kartu garansi. Untuk menentukan besarnya sampel dalam penelitian ini mengacu pada rumus Slovin.

Penelitian ini mengambil data pelanggan AHASS Sumber Jaya Maha Sakti Kecamatan Rogojampi Kabupaten Banyuwangi selama bulan Februari 2017 dengan jumlah data sebanyak 843 pelanggan. Jadi berdasarkan populasi sebanyak 843 pelanggan tersebut dapat dicari sampelnya sebanyak 90 responden.

Jenis data dalam penelitian ini adalah data kuantitatif dan kualitatif.Data kuantitatif adalah data yang dapat dinyatakan dengan angka-angka, data kuantitatif dari penelitian ini berupa jawaban kuesioner.Sedangkan data kualitatif dari penelitian ini berupa hasil wawancara dan observasi ke tempat penelitian.Sumber data penelitian ini meliputi data primer dan sekunder.Data primer didapatkan langsung dari pelanggan AHASS melalui pengisian kuesioner sedangkan data sekunder didapatkan dari dokumen tertulis di AHASS Kecamatan Rogojampi Kabupaten Banyuwangi. Sumber data yang digunakan dalam penelitian ini adalah sebagai berikut:

1. Responden yaitu pelanggan AHASS Sumber Jaya Maha Sakti.

2. Informan dalam penelitian ini yaitu manajer AHASS Sumber Jaya Maha Sakti.

3. Dokumen dalam penelitian yaitu dokumen yang ada di AHASS Sumber Jaya Maha Sakti yang diperoleh dari manajer dan bagian administrasi umum.

Analisis Deskriptif, analisis ini untuk menggambarkan keadaan lapangan daerah penelitian secara deskriptif dengan jalan menginterprestasikan hasil tabulasi data dengan harapan dapat mendukung hasil analisis penelitian, sehingga dapat menjabarkan secara rinci untuk mengetahui gambaran tentang pengaruh kualitas pelayanan terhadap kepuasan pelanggan AHASS Sumber Jaya Maha Sakti.

Analisis Inferensial, analisis ini merupakan analisis statistik dengan menggunakan persamaan regresi linier sederhana. Analisis regresi linier sederhana ini digunakan untuk menggambarkan kualitas pelayanan terhadap kepuasan pelanggan AHASS Sumber Jaya Maha Sakti Kecamatan Rogojampi Kabupaten Banyuwangi. Dalam penelitian ini menggunakan satu predikator yaitu kualitas pelayanan 
sebagai (X). Model persamaan analisis regresi linier sederhana dalam penelitian ini adalah sebagai berikut:

$$
\mathrm{Y}=\mathrm{a}+\mathrm{bX}
$$

Keterangan:

a : Konstanta

b : Koefisien Regresi

Y : Kepuasan Pelanggan

$\mathrm{X} \quad$ : Kualitas Pelayanan

\section{HASIL DAN PEMBAHASAN}

\section{Hasil Analisis Regresi Linier Sederhana}

Analisis garis regresi sederhana digunakan untuk mengetahui pengaruh antara variabel kualitas pelayanan(X) terhadap kepuasan pelanggan di AHASS Sumber Jaya Maha Sakti Kecamatan Rogojampi Kabupaten Banyuwangi(Y). Pada penelitian ini, dilakukan menggunakan analisis garis regresi sederhana dengan menggunakan program SPSS 22.0 for windows. Hasil analisis disajikan pada tabel berikut ini.

Tabel 1. Ringkasan Hasil Analisis Regresi Logistik

\begin{tabular}{|c|l|c|}
\hline Variabel & \multicolumn{1}{|c|}{ Label } & Koefisien Regresi \\
\hline $\mathrm{a}$ & Konstanta & 0,259 \\
\hline $\mathrm{X}$ & Kualitas Layanan & $0,599^{\mathrm{TS}}$ \\
\hline \multicolumn{2}{|l|}{ R Square $=0,790$} \\
Multiple R $=0,889$ \\
F rasio $=330,218$ \\
\hline
\end{tabular}

Sumber: SPSS data diolah

Berdasarkan Tabel di atas tersebut, maka persamaan garis regresi sederhana yang diperoleh dalam penelitian ini adalah sebagai berikut:

$$
\hat{\mathrm{Y}}=-3,353+0,338 \mathrm{X}+\mathrm{ei}
$$

Sesuai dengan persamaan regresi yang diperoleh, maka model regresi tersebut dapat diinterpretasikan sebagai berikut:

Nilai konstanta menunjukkan nilai negatifsebesar -3,353. Hal ini menunjukkan apabila variabel kualitas pelayanan dan ei nilainya konstan (nol), maka kepuasan pelanggan di AHASS Sumber Jaya Maha Sakti Kecamatan Rogojampi Kabupaten Banyuwangisebesar -3,353.

Koefisien regresi kualitas pelayanan (X). Berarti bahwa apabila nilai variabel kualitas pelayanan mengalami kenaikan sebesar satu poin, sementara variabel independen lainnya bersifat tetap, maka variabel Y yaitu kepuasan pelanggan di AHASS Sumber Jaya Maha Sakti Motor Kecamatan Rogojampi Kabupaten Banyuwangi akan mengalami peningkatan sebesar 0,338 point.

Analisis ini digunakan untuk mengetahui kuat tidaknya atau untuk mengetahui tingkat keeratan komponen kualitas pelayanan (X) terhadap kepuasan pelanggan di AHASS Sumber Jaya Maha Sakti Kecamatan Rogojampi Kabupaten Banyuwangi (Y). Berdasarkan perhitungan di atas dapat diketahui bahwa nilai koefisisen korelasi sebesar 0,889 berarti bahwa kualitas pelayanan(X) memiliki hubungan yang nyata/signifikan dengan kepuasan pelanggan di AHASS Sumber Jaya Maha Sakti Kecamatan Rogojampi Kabupaten Banyuwangi (Y). Tingkat hubungan tersebut dapat dikategorikan sebagai hubungan yang sangat kuat.Tabel yang menunjukkan interpretasi terhadap koefisien korelasi bisa terlihat sebagai berikut yang digunakan sebagai interpretasi terhadap koefisien korelasi. 
Berdasarkan tabel di atas, diketahui bahwa besarnya $\mathrm{F}_{\text {hitung }}=330,218>\mathrm{F}_{\text {tabel }}=3,949$ dengan tingkat signifikansi $\mathrm{F}=0,000<a=0,05$. Hal ini menunjukkan bahwa variabel kualitas pelayanan memiliki pengaruh yang signifikan terhadap kepuasan pelanggan di AHASS Sumber Jaya Maha Sakti Kecamatan Rogojampi Kabupaten Banyuwangi. Berdasarkan data tersebut dapat disimpulkan bahwa Ho ditolak dan Ha diterima yaitu 'ada pengaruh yang signifikan kualitas pelayanan terhadap kepuasan pelanggan di AHASS Sumber Jaya Maha Sakti Kecamatan Rogojampi Kabupaten Banyuwangi’.

Koefisien determinasi digunakan untuk mengukur besarnya proporsi sumbangan variabel bebas yaitu kualitas pelayanan (X) terhadap variabel terikat yaitu kepuasan pelanggan di AHASS Sumber Jaya Maha Sakti Kecamatan Rogojampi Kabupaten Banyuwangi (Y). Hasil SPSS 22.0 for windows diperoleh nilai koefisien determinasi $\left(\mathrm{R}_{\text {square }}\right)$ sebesar 0,790 .

$$
\mathrm{R}_{\text {square }} \times 100 \%=0,790 \times 100 \%=79 \%
$$

Hal ini menunjukkan bahwa besarnya persentase pengaruh kualitas pelayanan terhadap kepuasan pelanggan di AHASS Sumber Jaya Maha Sakti Kecamatan Rogojampi Kabupaten Banyuwangisebesar $79 \%$, sedangkan sisanya yaitu $21 \%$ dipengaruhi variabel bebas lainnya yang tidak diteliti dalam penelitian ini meliputi harga, potongan harga, lokasi, dan lain-lain.

Standart Error Of Estimate digunakan untuk mengukur variasi nilai $\mathrm{Y}$ aktual dari garis regresinya sehingga akan diketahui tingkat representatif garis regresinya. Hasil pengolahan data bagian model Summary menunjukkan bahwa nilai StandartError Of Estimate dalam analisis garis linier sederhana sebesar 0,75615. Hal tersebut menunjukkan bahwa variasi nilai $Y$ actual dari garis regresinya adalah sebesar 0,75615. Besarnya Standart Error Of Estimate sebesar 0,75615 menunjukkan besarnya penyimpangan variabel kepuasan pelangganterhadap garis regresinya.

Hal ini berarti bahwa kepuasan pelanggantidak hanya dipengaruhi kualitas pelayanan saja, namun juga dipengaruhi oleh variabel lain yang tidak diteliti dalam penelitian ini seperti harga, potongan harga, lokasi, dan lain-lain.

Kualitas pelayanan yang diharapkan oleh pelanggan sebagai penerima layanan mengharapkan tingkat keunggulan dari setiap jasa pelayanan yang didapat dari pelayanan yang didapatkan sebelumnya. Jika pelayanan yang diberikan melampaui harapan pelanggan maka kualitas pelayanan yang diberikan akan mendapatkan persepsi yang ideal dari para penerima pelayanan. Oleh karena itulah kualitas sangat penting bagi para penjual jasa. Hal ini dikarenakan dengan adanya kualitas pelayanan yang maksimal, maka dapat memberikan rasa puas kepada pelanggan.

Berdasarkan penelitian dan analisis data yang dilakukan dapat diketahui bahwa ada pengaruh yang signifikan kualitas pelayanan terhadap kepuasan pelanggan di AHASS Sumber Jaya Maha Sakti Kecamatan Rogojampi Kabupaten Banyuwangi. Hal tersebut dapat dilihat dari hasil uji besarnya $\mathrm{F}_{\text {hitung }}=330,218>\mathrm{F}_{\text {tabel }}=3,949$ dengan tingkat signifikansi $\mathrm{F}=0,000<a=0,05$. Sedangkan untuk proporsi pengaruh kualitas pelayanan terhadap kepuasan pelanggan di AHASS Sumber Jaya Maha Sakti Kecamatan Rogojampi Kabupaten Banyuwangisebesar 79\%. sedangkan sisanya yaitu 21\% dipengaruhi variabel bebas lainnya yang tidak diteliti dalam penelitian ini meliputi harga, potongan harga, lokasi, dan lain-lain.

Adanya rasa puas yang dirasakan oleh pelanggan menandakan bahwa pelayanan yang diberikan oleh pihak AHASS tersebut telah berhasil dan sesuai dengan keinginan dan kebutuhan dari pelanggan. Hal ini sesuai dengan pendapat Lupiyoadi dan Hamdani, (2006:192) yang menyatakan bahwa kualitas pelayanan memiliki hubungan yang erat dengan kepuasan pelanggan. Jadi, hal yang terpenting dalam suatu usaha jasa adalah kualitas pelayanan dalam bentuk jasa yang hendak diberikan kepada pelanggan. Berikut merupakan hasil wawancara yang dilakukan oleh peneliti dengan salah satu karyawan AHASS 
Sumber Jaya Maha SaktiKecamatan Rogojampi Kabupaten Banyuwangi yang menjadi informan dalam penelitian ini.

“................., Kami berusaha memberikan kualitas pelayanan yang terbaik untuk pelanggan mbak. Hal ini dikarenakan dengan memberikan pelayanan yang maksimal kepada pelanggan, seperti dengan cepat melayani pelanggan sehingga tidak terjadi antrian yang panjang, serta kami berusaha memberikan solusi terbaik jika ada pelanggan yang mengalami kesulitan. Oleh karena itulah pelanggan banyak yang tetap menggunakan jasa kami mbak." (NM, 39 Th).

Dari penjelasan tersebut, dapat diketahui bahwa dengan adanya kualitas pelayanan dapat mempengaruhi kepuasan pelanggan AHASS Sumber Jaya Maha Sakti Kecamatan Rogojampi Kabupaten Banyuwangi. Dimana kualitas pelayanan yang diberikan tersebut meliputi bukti fisik, keandalan, daya tanggap, jaminan, dan empati.

Bukti fisik merupakan penampilan fisik fasilitas layanan, peralatan/perlengkapan, sumber daya manusia, dan materi komunikasi perusahaan(Tjiptono,2008:106). Berdasarkan angket yang telah disebar kepada responden yang merupakan pelanggan yang menggunakan jasa pelayanan dari AHASS Sumber Jaya Maha Sakti Kecamatan Rogojampi Kabupaten Banyuwangi dapat diketahui bahwa keadaan ruang tunggu di AHASS Sumber Jaya Maha Sakti ketika menunggu service sangat nyaman, karena ruangan terasa tidak panas dan cukup cahaya, peralatan yang digunakan di AHASS Sumber Jaya Maha Sakti sudah baik, karena peralatan yang digunakan canggih, lengkap dan sesuai standart AHASS. Selain itu, penampilan karyawan AHASS Sumber Jaya Maha Sakti sangat rapi, bersih dan memakai seragam sesuai dengan jenis pekerjaannya, kondisi ruang service AHASS Sumber Jaya Maha Sakti sudah baik, karena perlatan tertata rapi dan terdapat ruang pandang yang jelas untuk melihat kendaraan yang sedang diperbaiki.

Keandalan merupakan kemampuan karyawan perusahaan jasa untuk memberikan pelayanan yang dijanjikan dengan segera, akurat, dan memuaskan kepada setiap pelanggan(Tjiptono,2007:273). Berdasarkan angket yang telah disebar kepada responden yang merupakan pelanggan yang menggunakan jasa pelayanan dari AHASS Sumber Jaya Maha Sakti Kecamatan Rogojampi Kabupaten Banyuwangidapat diketahui bahwa penyelesaian sevice di AHASS Sumber Jaya Maha Sakti memuaskan, karena penyelesaian service cepat dan sesuai dengan waktu yang dijanjikan, kinerja karyawan dalam melakukan service bagus, karena sesuai dengan keluhan dan permintaan. Selain itu, sikap karyawan di AHASSSumber Jaya Maha Sakti ketika pelanggan datang kesana sangat simpatik dan mendengarkan keluhan yang dialami danpihak AHASS sudah memberikan pelayanan yang baik kepada semua pengguna jasa service tanpa membeda-bedakan.

Berikut merupakan hasil wawancara yang dilakukan oleh peneliti dengan salah satu pelanggan AHASS Sumber Jaya Maha Sakti Kecamatan Rogojampi Kabupaten Banyuwangi yang menjadi responden dalam penelitian ini.

"Saya merasa sangat puas dengan pelayanan yang diberikan oleh karyawan AHASS Sumber Jaya Maha Sakti mbak, karena dapat menyelesaikan service cepat dan sesuai dengan waktu yang dijanjikan, kinerja karyawan dalam melakukan service juga bagus mbak, karena sesuai dengan keluhan dan permintaan. Selain itu, sikap karyawan di AHASS Sumber Jaya Maha Sakti ketika saya datang ke sana sangat simpatik dan mendengarkan keluhan yang saya alami" (AR, $45^{\mathrm{Th}}$ ).

Berdasarkan penjelasan tersebut dapat diketahui bahwa keandalan yang diberikan oleh AHASS Sumber Jaya Maha Sakti Motor Kecamatan Rogojampi Kabupaten Banyuwangi dapat memberikan rasa puas kepada para pelanggan. Hal ini menunjukkan bahwa pelanggan pada AHASS Sumber Jaya Maha Sakti Kecamatan Rogojampi Kabupaten Banyuwangi memiliki kinerja yang baik. Untuk indikator selanjutnya yaitu daya tanggap. 
Daya tanggap yaitu suatu kebijakan untuk membantu dan memberikan pelayanan yang cepat (responsif) dan tepat kepada pelanggan, dengan penyampaian informasi yang jelas serta tidak membiarkan pelanggan menunggu agar tidak menciptakan persepsi yang negatif dari kualitas pelayanan (Lupiyoadi,2013:217). Berdasarkan angket yang telah disebar kepada responden yang merupakan pelanggan yang menggunakan jasa pelayanan dari AHASS Sumber Jaya Maha Sakti Kecamatan Rogojampi Kabupaten Banyuwangi dapat diketahui bahwa antrian di service di AHASS Sumber Jaya Maha Sakti sangat baik, karena urutan service sesuai dengan nomer antrian, karyawan berusaha memberikan solusi terbaik ketika pelanggan menyampaikan keluhan tentang kendaraan motor pelanggan yang mengalami kerusakan, dan karyawan sangat siap tanggap ketika pelanggan baru datang ke AHASS Sumber Jaya Maha Sakti.

Jaminan mencakup pengetahuan, kemampuan, kesopanan, dan sifat dapat dipercaya yang dimiliki perusahaan(Tjiptono,2006:70). Berdasarkan angket yang telah disebar kepada responden yang merupakan pelanggan yang menggunakan jasa pelayanan dari AHASS Sumber Jaya Maha Sakti Kecamatan Rogojampi Kabupaten Banyuwangi dapat diketahui bahwa karyawan sangat mampu, karena ketika pelanggan menyampaikan keluhan, karyawan langsung mengerti apa yang perlu diganti dan apa yang harus diperbaiki, pihak AHASS memberikan garansi jika terjadi kesalahan oleh karyawan, konsumen merasa sangat merasa aman, karena spare part yang digunakan atau yang diganti adalah asli merek Honda, dan karyawan sudah bersikap jujur dan dapat dipercaya ketika jasa service dilakukan.

Empati (empathy) yaitu memberikan perhatian yang tulus dan bersifat individual atau pribadi yang diberikan kepada para pelanggan dengan berupaya memahami keinginan konsumen(Lupiyoadi,2006:182). Berdasarkan angket yang telah disebar kepada responden yang merupakan pelanggan yang menggunakan jasa pelayanan dari AHASS Sumber Jaya Maha Sakti Kecamatan Rogojampi Kabupaten Banyuwangi dapat diketahui bahwa karyawan berkomunikasi dengan sangat baik, ramah dan sopan ketika melayani pelanggan, karyawan memberikan kemudahan dalam menggunakan jasa service kepada pelanggan. Selain itu, karyawan sangat memberikan informasi yang pelanggan butuhkan terkait service yang pelanggan lakukan di AHASS Sumber Jaya Maha Sakti.

Berikut merupakan penejelasan tambahan dari salah satu pelanggan AHASS Sumber Jaya Maha Sakti Kecamatan Rogojampi Kabupaten Banyuwangi yang menjadi responden dalam penelitian ini.

“................., Saya sangat puas dengan semua pelayanan yang diberikan oleh pihak AHASS Sumber Jaya Maha Sakti mbak, lokasi yang bersih dan karyawan yang berpakaian rapi, serta karyawan yang sangat menguasai pekerjaannya mbak. Mereka dapat memberikan pelayanan yang benar-benar maksimal, seperti sopan dan ramah, dengan cepat melayani dan menanggapi keluhan, dan tidak membeda-bedakan pelanggan mbak. Oleh akrena itulah saya menjadi pelanggan tetap pada AHASS Sumber Jaya Maha Sakti ini mbak" (AR, 45 Th).

Berdasarkan penjelasan tersebut dapat diketahui bahwa dengan adanya kualitas pelayanan yang maksimal dapat memberikan kepuasan kepada pelanggan. Salah satu faktor yang menentukan kepuasan pelanggan adalah persepsi pelanggan mengenai kualitas pelayanan yang terdiri dari lima dimensi yaitu bukti fisik, keandalan, daya tanggap, jaminan, empati (Rangkuti, 2002:41). Pelanggan yang merasa puas, maka pelanggan tersebut akan datang secara terus menerus dan menjadi pelanggan tetap.

Dimana bentuk dari kepuasan pelanggan dalam penelitian ini yaitu, kualitas pelayanan AHASS Sumber Jaya Maha sakti sudah sangat sesuai dengan harapan dan keinginan pelanggan, pelanggan memutuskan untuk menggunakan jasa service AHASS, apakah akan melakukan penggunaan jasa kembali jika suatu saat kendaraan sepeda motor terjadi kerusakan, pelanggan berminat menggunakan 
kembali jasa service AHASS, pelanggan akan menginformasikan jasa service AHASS kepada teman, sahabat dan keluarga. Selain itu, pelanggan pernah mengajak teman, saudara atau keluarga untuk menggunakan jasa service AHASS Sumber Jaya Maha Sakti, karena pelanggan ingin menunjukkan kepada teman, saudaraatau keluarga pelanggan tentang pelayanan jasa service AHASS Sumber Jaya Maha Sakti

Kualitas pelayanan merupakan syarat kelangsungan hidup perusahaan, tingginya kualitas yang diberikan akan mencerminkan pada aspek kepuasan para pelanggan. Menurut Alma (2000:279) hal penting perusahaan dalam menjalankan usahanya adalah penerapan kualitas pelayanan sehingga tercapai kepuasan pelanggan yang pada akhirnya meningkatkan loyalitas konsumen dan tidak terbujuk untuk berpindah perusahaan lain. Kepuasan pelanggan akan tercipta apabila kualitas pelayanan yang diberikan perusahaan baik dan sesuai dengan harapan dan kebutuhan pelanggan namun jika kualitas yang diberikan rendah maka akan mengakibatkan rasaketidakpuasan dari pelanggan. Kepuasan pelanggan akan membentuk persepsi yang positif terhadap perusahaan dan pelayanan yang bermutu dapat dilakukan dengan meningkatkan kualitas pelayanan. Maka dari itu AHASS mengutamakan kepuasan pelanggan dengan memberikan kualitas pelayanan yang baik.

\section{PENUTUP}

Berdasarkan hasil penelitian dan pembahasan mengenai kualitas pelayanan terhadap kepuasan pelanggan di AHASS Sumber Jaya Maha Sakti Motor Kecamatan Rogojampi Kabupaten Banyuwangi dapat disimpulkan bahwa ada pengaruh yang signifikan kualitas pelayanan terhadap kepuasan pelanggan di AHASS Sumber Jaya Maha Sakti Motor Kecamatan Rogojampi Kabupaten Banyuwangi yaitu sebesar $79 \%$, sedangkan sisanya yaitu $21 \%$ dipengaruhi variabel bebas lainnya yang tidak diteliti dalam penelitian ini meliputi harga, potongan harga, lokasi, dan lain-lain.

Berdasarkan kesimpulan dari penelitian ini maka dapat diberikan saran pada beberapa pihak adalah sebagai berikut:

1. Pihak AHASS Sumber Jaya Maha Sakti Motor, hendaknya meningkatkan kinerja karyawan serta memberikan beberapa potongan harga untuk dapat menarik para pelanggan.

2. Bagi karyawan, hendaknya lebih meningkatkan kualitas pelayanan terutama dalam hal daya tanggap yang diberikan oleh karyawan kepada pelanggan.

3. Bagi peneliti lain, untuk ikut mempertimbangkan sumbangan pengaruh variabel bebas lain yang tidak diteliti dalam penelitian ini. Oleh karena itu diharapkan bagi peneliti lain yang akan melakukan penelitian serupa dengan penelitian ini untuk mengambil variabel lain yang tidak turut diteliti dalam penelitian ini.

\section{DAFTAR PUSTAKA}

Alma, Buchari. 2000. Manajemen Pemasaran dan Pemasaran Jasa. Ediai Revisi. Bandung: Penerbit CV Alfabeta.

Kotler, P and Keller, L. 2009. Marketing Management, 13 Edition. New York: Prentice Hall.

Kotler, Philip and Gary Armstrong. 2007. Prinsip-prinsip Pemasaran. Edisi. 12. Jilid 1. Jakarta: Erlangga.

Kotler, Philip. 2008. Marketing Management, Eleventh Edition, New Jersey: Prentice-Hall International, Inc.

Lupiyoadi, Rambat dan A. Hamdani. 2006. Manajemen Pemasaran Jasa. Edisi Kedua. Jakarta: Penerbit Salemba Empat.

Lupiyoadi, Rambat. 2006. Manajemen Pemasaran Jasa. Jakarta: Penerbit Salemba Empat. 
Rangkuti, Freddy. 2006. Measuring Customer Satisfaction. cetakan kedua. Jakarta: Penerbit PT. Gramedia Pustaka Utama.

Swastha, Basu. 2006. Manajemen Pemasaran. Edisi Kedua. Cetakan Kedelapan. Yogyakarta: Penerbit Liberty.

Tjiptono, Fandi. 2006. Perspektif Manajemen dan Pemasaran Kontemporer. Yogyakarta: Andi.

Yazid. 2008. Pemasaran Jasa. Edisi Kedua. Yogyakarta: Ekonisia Kampus. 